\title{
Dual-polarity Early Carboniferous remagnetization of the Fisset Brook Formation, Cape Breton Island, Nova Scotia
}

\author{
Rex J. E. Johnson and Rob Van der Voo \\ Department of Geological Sciences, University of Michigan, Ann Arbor, MI 48109-1063, USA,
}

Accepted 1988 October 19. Received 1988 September 29; in original form 1987 April 29

\begin{abstract}
SUMMARY
Red siltstones and volcanic flows of the Fisset Brook Formation of Cape Breton Island, Nova Scotia, were folded or tilted in two phases, one of Late Tournaisian and the other of Mid-Namurian age. Upon thermal demagnetization, both rock types yield three components of magnetization, herein denoted as $\mathrm{L}, \mathrm{I}$ and $\mathrm{H}$. The $\mathrm{L}$ component has low unblocking temperatures and a direction conforming to that of the present-day geomagnetic field. $\mathrm{L}$ is inferred to be of recent origin. The intermediate I component, carried by haematite, is of synfolding origin. Directions could be obtained through vector subtraction for the demagnetization interval of $300-550^{\circ} \mathrm{C}$, and yield a mean of $D / I=160^{\circ} /+38^{\circ}\left(k=90.8, \alpha_{95}=5.1^{\circ}\right)$, after 39 per cent of the tilt correction is applied. The $\mathrm{H}$ component has even higher unblocking temperatures, which overlap to a large degree with those of the I component, but analysis of intersecting great circles appears to yield a best-fit direction for $\mathrm{H}$ which is nearly antipodal to that of the $\mathrm{I}$ component. $\mathrm{H}$ is also synfolding, and yields a mean direction of $D / I=342^{\circ} /-38^{\circ}\left(k=120.9, \alpha_{95}=6.9^{\circ}\right)$ after 60 per cent of tilt correction. Both components are interpreted as secondary chemical remanent magnetizations of Late Tournaisian to Early Namurian age. A comparison of all available Carboniferous results from the craton and the northern Appalachians indicates that palaeolatitudes for Nova Scotia changed from about $20^{\circ} \mathrm{S}$ to about $10^{\circ} \mathrm{S}$ in the interval between the Early and Late Namurian and that they changed again from about $10^{\circ} \mathrm{S}$ to $0^{\circ}$ between the Late Namurian and the Stephanian. Declinations show good agreement between Newfoundland, Nova Scotia, New Brunswick and the craton, with the exception of the Meguma terrain, which underwent a counterclockwise rotation with respect to the mainland in the Late Carboniferous, as noted previously by Spariosu, Kent \& Keppie (1984).
\end{abstract}

Key words: Avalon zone, overprint magnetization, palaeomagnetism, terrains

\section{INTRODUCTION}

The Avalon terrain is one of several suspect terrains recognized in the northern Appalachians (Williams \& Hatcher 1983). Palaeomagnetic results obtained from rocks of Early Palaeozoic age from N Avalon reveal that this terrain was widely separated from America $\left(20-40^{\circ}\right)$ at least until the end of the Ordovician period (Johnson \& Van der Voo 1985; Van der Voo \& Johnson 1985). However, owing to a scarcity of palaeomagnetic results from Avalon for the interval between Late Ordovician and Early Carboniferous times, its position during the Mid-Palaeozoic remains poorly constrained. Although palaeomagnetic results from rocks of Early Carboniferous age from Avalon and N America indicate that Avalon was probably accreted to the craton by then (Irving \& Strong 1984; Kent \& Opdyke, 1985; Murthy 1985), it is specifically not known when this accretion actually occurred. The present study, which describes new palaeomagnetic results from the Late Devonian Fisset Brook Formation of the Avalon terrain of Nova Scotia, was undertaken in an attempt to document the position of
Avalon in the Late Devonian. By comparing the results obtained in this study with the newly revised Late Devonian palaeomagnetic results for cratonic North America (Miller \& Kent 1986a,b) we had hoped to be able to test whether Avalon was accreted to $\mathrm{N}$ America by the Late Devonian time, or, if not, to infer the nature of the post-Devonian displacement between these blocks. However, in view of the fact that the Fisset Brook Formation appears to be remagnetized, such a test is not possible, yet the age of the resultant direction for this formation is well constrained and it provides important information about the position of the Avalon terrain.

\section{GEOLOGY AND SAMPLING}

Upper Devonian volcanics and associated sediments that unconformably overlie Avalonian basement rocks in NW Cape Breton Island comprise the Fisset Brook Formation (e.g. Keppie 1979). Although originally defined in the area between Lake Ainslie and Cheticamp (Fig. 1) (Kelley \& MacKasey 1963), similar strata outcropping intermittently 


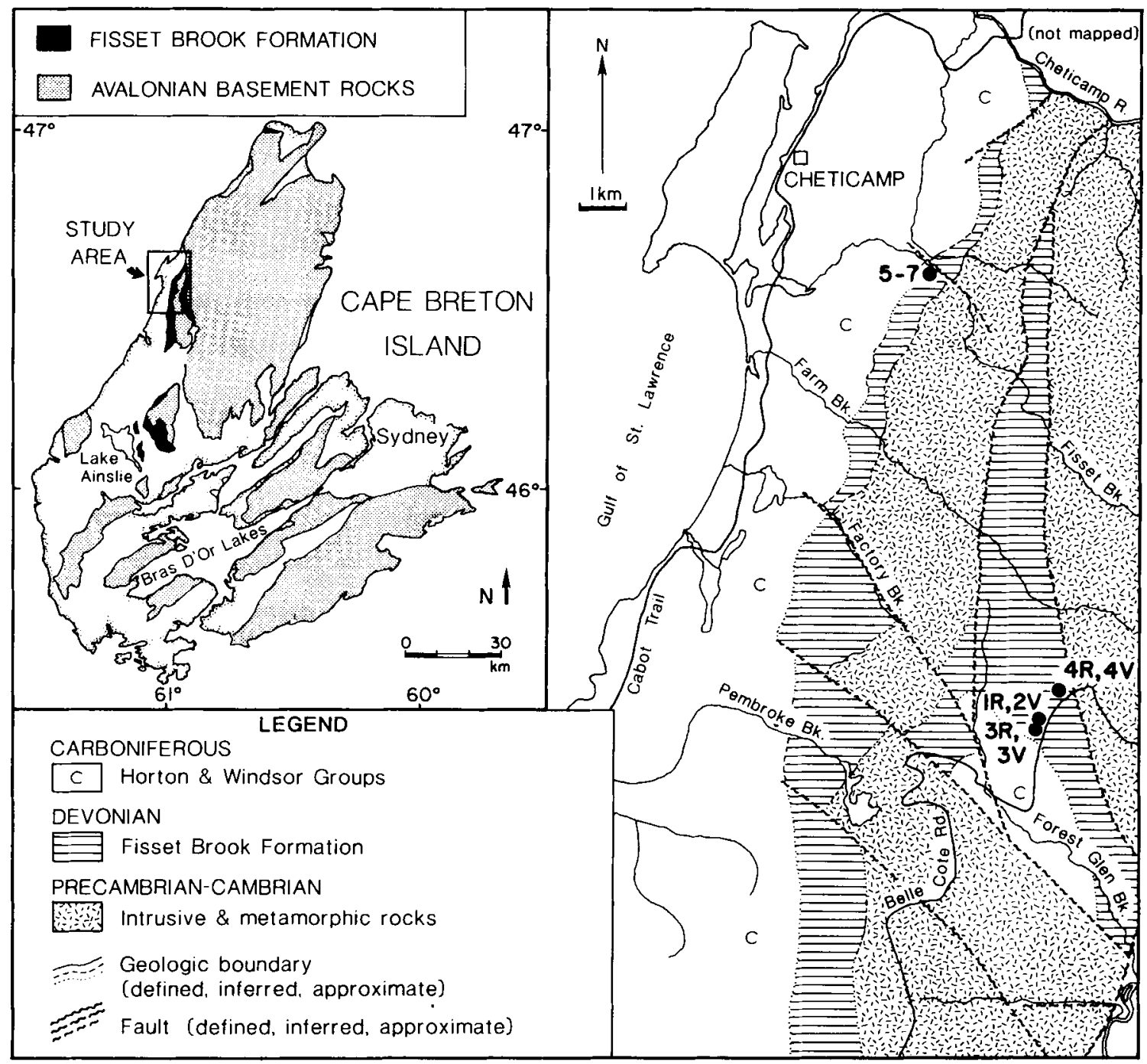

Figure 1. Generalized geologic map of the study area in NW Cape Breton Island, Nova Scotia, showing the location of numbered palaeomagnetic sampling sites in the Fisset Brook Formation (after Blanchard et al. 1984; Barr et al. 1986). The location of the study area is shown in the inset map.

throughout northwestern Cape Breton have been correlated with this unit (e.g. Jamieson \& Craw 1983). Volcanic rocks of this age in Maritime Canada are thought to record a phase of rifting which preceded the Early Carboniferous development of fault-bounded basins in this region (e.g. Poole et al. 1970; Bradley 1982).

We studied the Fisset Brook Formation in the two main outcrop belts south of Cheticamp (Fig. 1), where it consists of approximately equal proportions of intercalated volcanics and redbeds with a total thickness of approximately $300 \mathrm{~m}$. The volcanics are predominantly basalt flows, although rhyolites and agglomeratic units are observed near the base of the formation (Blanchard, Jamieson \& More 1984). The thickness of individual flows ranges from $2 \mathrm{~m}$ to about $30 \mathrm{~m}$. The intercalated sediments are predominantly well-bedded red haematitic siltstones, except in the basal part of the unit which includes some pebble conglomerates and coarser clastics. Abundant plant remains as well as sedimentary structures (e.g. raindrop imprints) preserved in the siltstones are consistent with a terrestrial origin, probably in an alluvial fan depositional setting. The well-preserved plant fossils and spores from the eastern as well as the western outcrop belts indicate an Upper Devonian age for the Fisset Brook Formation (Kelley \& MacKasey 1963; Jamieson \& Craw 1983). In addition, volcanics from the western belt have yielded a whole-rock $\mathrm{Rb}-\mathrm{Sr}$ age of $376 \pm 12 \mathrm{Myr}$ (Cormier \& Kelly 1964; Jamieson \& Craw 1983).

The study area is located along the $\mathrm{SW}$ margin of a major horst block that was a relative structural high during deposition of overlying Carboniferous sediments (Cape Breton Upland; Poole et al. 1970). The Fisset Brook strata in this area were tilted in the Early and Mid-Carboniferous as the result of episodic vertical displacements between the horst and the adjoining Antigonish-Mabou basin. The Fisset Brook Formation is conformable with the Lower Carboniferous (Tournaisian) Horton Group (Kelley \& MacKasey 1963), but an angular unconformity between the Horton Group and the overlying Windsor Group (see Fig. 2 ), which is observed in the Lake Ainslie area (Poole $e t$ al. 1970; Kelley 1967), suggests that one episode of tilting occurred during Late Tournaisian time. Elsewhere in this area, tilted Fisset Brook and Horton strata are in fault 


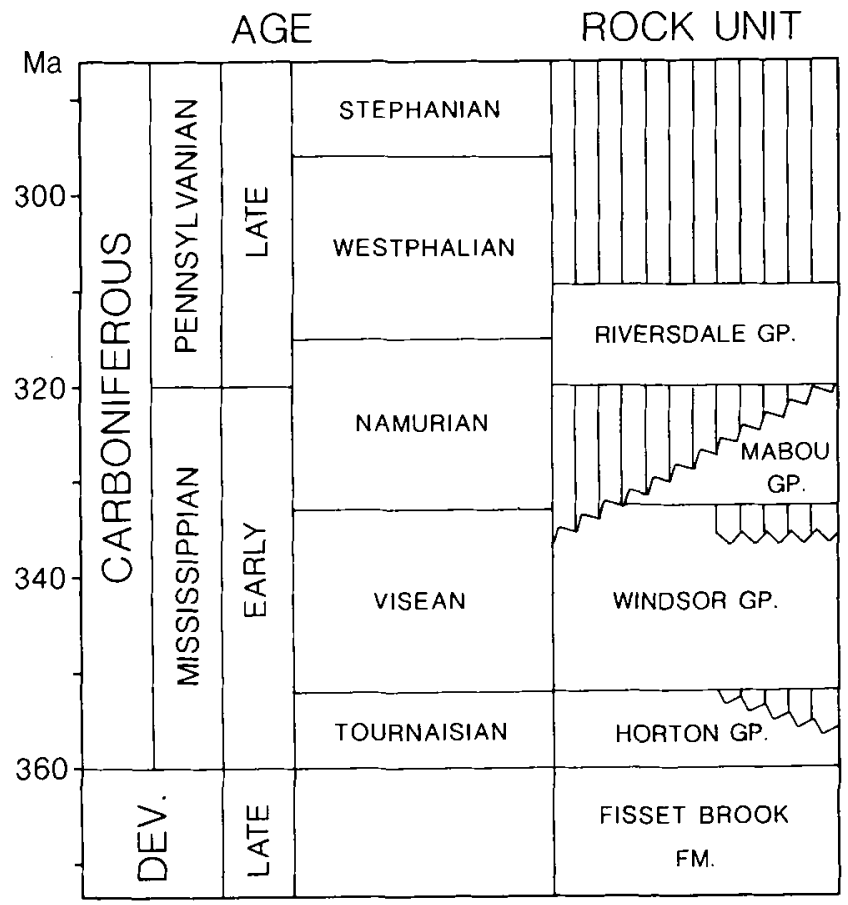

Figure 2. Late Devonian and Carboniferous stratigraphy of NW Cape Breton Island. The wavy line boundaries between rock units in the diagram indicate either disconformities (horizontal), or angular unconformities (inclined); all other boundaries are conformable. Vertical ruling represents hiatuses. Based on data from Poole et al. (1970); Currie (1977); timescale is from Palmer (1983).

contact with tilted and deformed Windsor Group strata (e.g. Currie 1977), thus implying that the pre-Windsor strata were tilted a second time. The second tilting event must have occurred prior to deposition of the overlying Upper Carboniferous Riversdale Group strata (Fig. 2) which are flat-lying (Currie 1977), and the age of this second tilting event is best placed in the Middle Namurian. The strike of bedding in the Fisset Brook Formation generally follows the trend of the outcrop belts along the margin of the horst, and both are probably controlled by the geometry of the basement block. Tilting of the Fisset Brook Formation was accompanied by locally intense faulting, but thick sections between the faulted zones reveal little or no internal deformation. While Blanchard et al. (1984) report evidence of possible hydrothermal alteration of the lavas, the Fisset Brook strata in the study area have not been metamorphosed.

The volcanics and redbeds of the Fisset Brook Formation were sampled at three localities (10 sites) in nearly flat-lying as well as moderately tilted strata so that a fold test could be performed (Fig. 1). Oriented core samples $(2.5 \mathrm{~cm}$ diameter) were obtained using a portable gas-powered drill with a diamond core bit, and oriented using a Brunton compass and inclinometer. Each site in the volcanics, designated by an upper case ' $V$ ', represents a single flow, while samples from the redbed sites (' $R$ ' sites) were generally taken over a stratigraphic thickness of 2-3 m from beds with a uniform lithology. Most of the redbed samples were fine-grained siltstones, but a few beds of medium- to coarse-grained arkose were sampled in addition to the siltstones at the first locality (site 1R), and these are designated site $1 R^{\prime}$. We note that bedding orientations for the volcanics were determined from the intercalated sediments.

\section{PALAEOMAGNETIC METHODS}

Standard palaeomagnetic specimens $(2.2 \times 2.5 \mathrm{~cm}$ diameter $)$ were prepared from oriented core samples, and their remanent magnetization was measured on either an ScT two-axis cryogenic magnetometer or a Schonstedt SSM-1A spinner magnetometer. Specimens were demagnetized using stepwise thermal, alternating field (AF) or chemical methods. Thermal and AF demagnetization experiments used a Schonstedt TSD-1 furnace and a Schonstedt GSD-1 single-axis AF demagnetizer. For chemical demagnetization, specimens of the redbeds were slotted (e.g. Henry 1978) and treated in field-free space in dilute $\mathrm{HCl}(8 \mathrm{~N})$.

Results for each specimen were plotted on orthogonal vector diagrams (Zijderveld 1967) as well as on equal-area projections. Best-fit 'demagnetization lines' and 'planes' were calculated for linear and planar demagnetization trajectories, identified from the graphs, using the principal component method of Kirschvink (1980). Demagnetization plane intersections were determined for components with overlapping spectra using the methods of Hoffman \& Day (1978) and Halls (1976). The program of Bailey \& Halls (1984) was used to estimate the precision and error associated with the intersection of great circles.

\section{PALAEOMAGNETIC RESULTS}

Natural remanent magnetization (NRM) intensities for the volcanics and redbeds have values of approximately $10^{-2}$ $\mathrm{A} \mathrm{m}^{-1}$ and $10^{-3} \mathrm{~A} \mathrm{~m}^{-1}$, respectively. Pilot specimens of both rock types revealed multivectorial magnetizations which were at least partially separated by thermal treatment. AF demagnetization to $100 \mathrm{mT}$ failed to produce decay of the remanence to the origin in several specimens, and this treatment method was thus discontinued. Chemical demagnetization of a few redbed specimens revealed noisy but approximately linear demagnetization trajectories, contrasting with the multicomponent behaviour of thermally demagnetized specimens from the same site or even the same sample. Such behaviour during chemical treatment suggests that the solubility spectra for different remanence components in the redbeds completely overlap one another, and chemical treatments were likewise discontinued. The majority of the remaining Fisset Brook specimens were therefore thermally demagnetized.

Typical thermal demagnetizations of volcanic and redbed specimens are shown in Fig. 3. The volcanics (Fig. 3a) characteristically show a large soft component of magnetization which is removed by about $320^{\circ} \mathrm{C}$. This component we will call $\mathrm{L}$ in this paper. The $\mathrm{L}$ component is approximately in the direction of the present-day field in situ and is probably of recent (viscous) origin. A medium unblocking temperature component is then removed between 350 and about $550{ }^{\circ} \mathrm{C}$ but the demagnetization trajectories do not tend toward the origin. Above $550^{\circ} \mathrm{C}$ the direction of the magnetic vector continues to change but the demagnetization trajectories are generally curved, indicating simul- 
a)

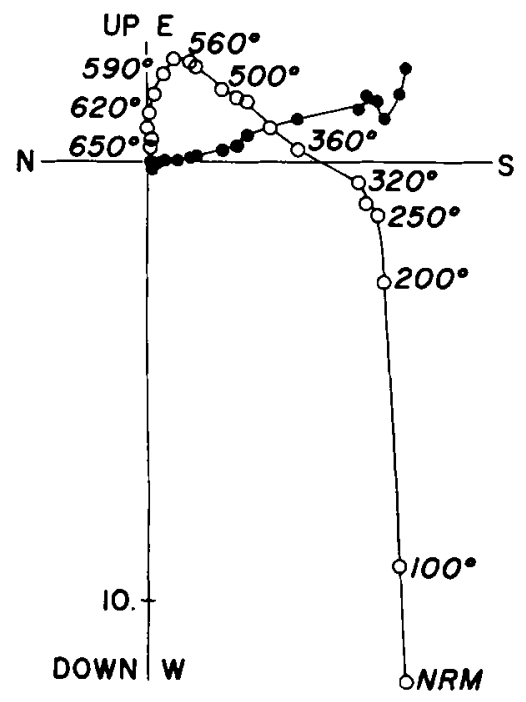

6V.A

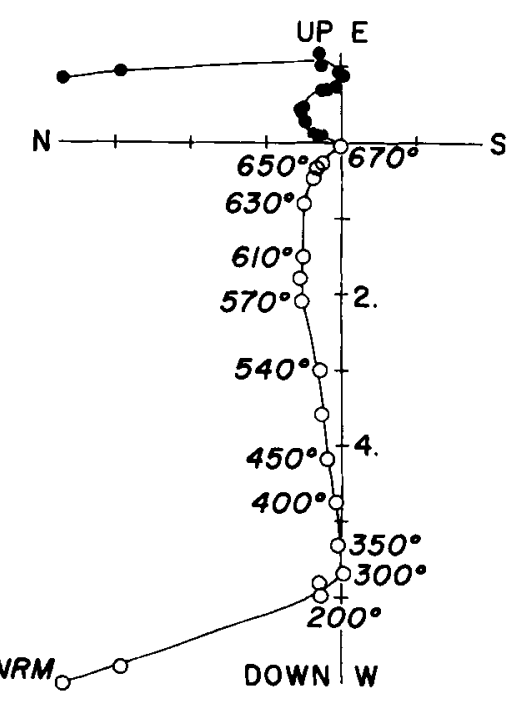

b)

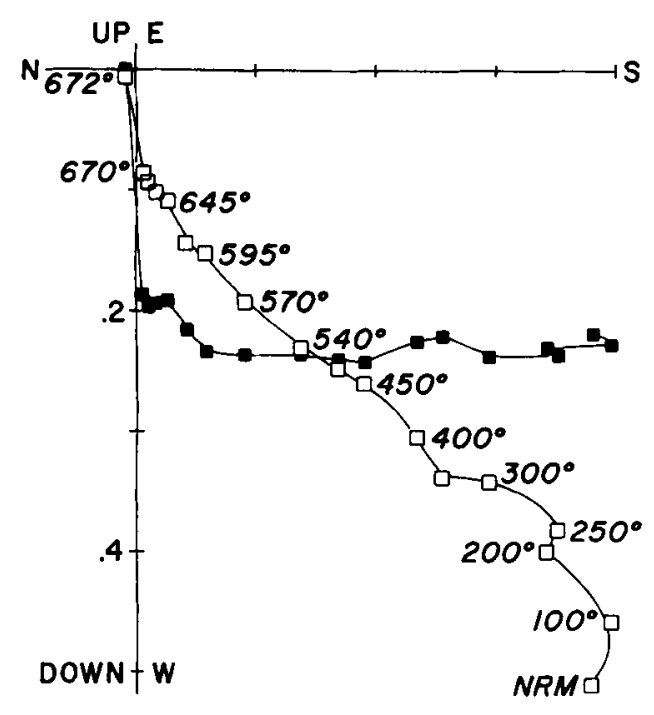

5R.A

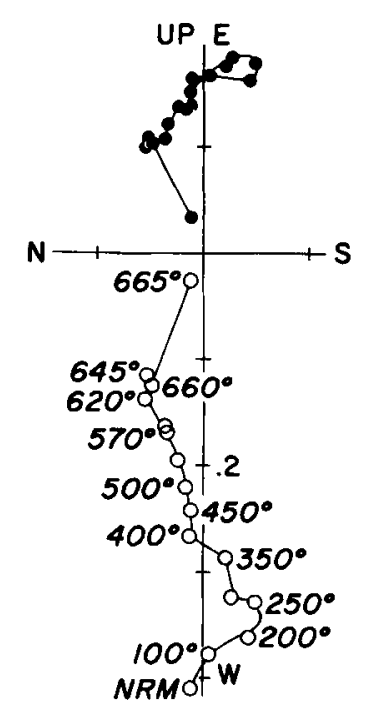

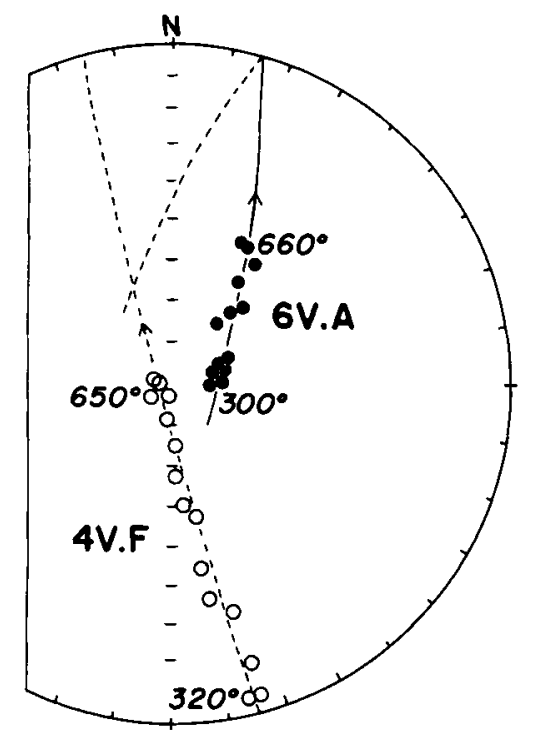

TR.D

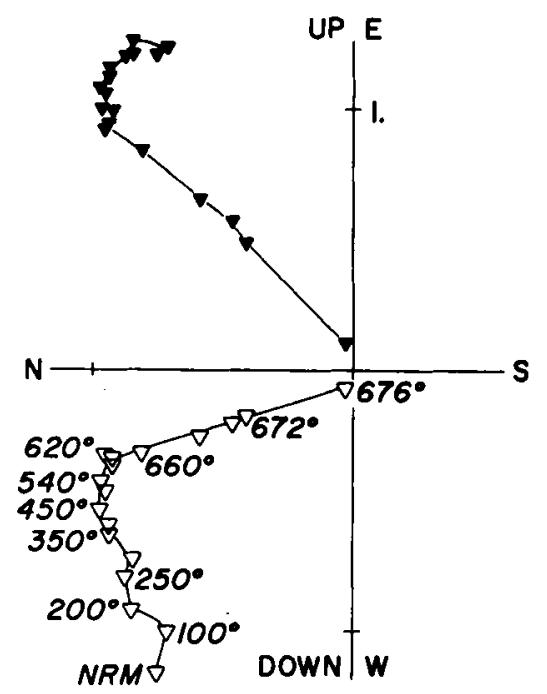

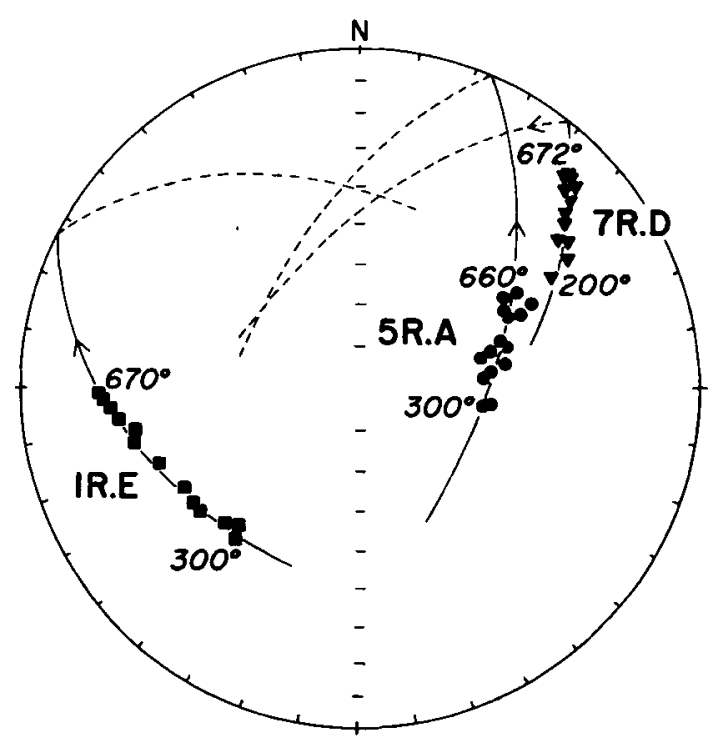


taneous removal of more than one component. Maximum unblocking temperatures $\left(T_{\mathrm{ub}}\right)$ for the volcanics are in the range of $625-675^{\circ} \mathrm{C}$. In most cases their demagnetization trajectories continued to curve through the last step of treatment (Fig. 3), thus preventing clear identification of the high- $T_{\mathrm{ub}}$ components from the Zijderveld diagrams. Thus, there are at least two higher unblocking temperature components in most of the samples; we will call these components I (intermediate) and $\mathrm{H}$ (high).

The behaviour of the redbeds is similar to that of the volcanics. They likewise exhibit some soft magnetization removed below $300^{\circ} \mathrm{C}$ which is directed downward (in situ) and may be a present-day field component, although it is not often clearly separated. For most redbed specimens the demagnetization trajectories above $300^{\circ} \mathrm{C}$ follow nearly linear trends that bypass the origin, corresponding to removal of the I component. Maximum unblocking temperatures for remanence in the majority of redbed specimens range up to $675^{\circ} \mathrm{C}$. In some redbed specimens the demagnetization trajectories are curved above $600{ }^{\circ} \mathrm{C}$. However, in many examples (1R.E; Fig. 3b) a more or less linear trajectory continues between 300 and $665^{\circ} \mathrm{C}$, followed by an abrupt drop in intensity to near zero in a narrow temperature interval. In most instances it is doubtful whether the component removed in the narrow temperature interval above $665^{\circ} \mathrm{C}$ represents a single (H) magnetization and, hence, a reliable stable endpoint direction. In a few specimens (e.g. 7R.D; Fig. 3b) linear decay toward the origin above $660^{\circ} \mathrm{C}$ is observed. However, analysis of sample demagnetization planes presented in the paragraphs below suggests that the apparent high-temperature stable endpoint direction, such as represented in specimen 7R.D, may be an artifact produced by simultaneous removal of the two components of magnetization ( $\mathrm{I}$ and $\mathrm{H}$ ) having quite different directions.

As revealed by the Zijderveld diagrams, as well as by the equal-area projections of successive directions for the remanence vector in each specimen during stepwise thermal demagnetization (Fig. 3), the remanence vectors for both the volcanics and redbeds tend toward a northerly and upward direction at progressively higher temperatures. Importantly, the equal-area projections show that successive directions for individual specimens, for treatments above $300^{\circ} \mathrm{C}$, appear to lie along a great circle path (plane), indicating that the magnetization remaining in specimens above this temperature is composed of just two components. Thus, the demagnetization diagrams reveal that in addition to the intermediate component (I) isolated on Zijderveld diagrams between $300^{\circ} \mathrm{C}$ and about $550^{\circ} \mathrm{C}$, only one other component $(\mathrm{H})$ is present in the volcanic and redbed specimens above $550^{\circ} \mathrm{C}$. Although the intermediate component could be isolated by vector subtraction between $300^{\circ} \mathrm{C}$ and $550^{\circ} \mathrm{C}$ in many samples, the overlapping unblocking temperature spectra for the I and $\mathrm{H}$ components above $550^{\circ} \mathrm{C}$ preclude a determination of the direction of $\mathrm{H}$ by vector subtraction alone.

We have used three techniques to determine the directions of the $\mathrm{I}$ and $\mathrm{H}$ components. The first technique is least-squares line-fitting to linear demagnetization trajectories, identified from the demagnetization diagrams, using principal component analysis (Kirschvink 1980). This first method enabled us to determine the I directions for eight sites (see Table 1) in which the I component was removed without apparent overlap with $\mathrm{L}$ or $\mathrm{H}$ in an intermediate temperature interval. The second technique, also based on Kirschvink's computer program, resembles the vector difference method of Hoffman \& Day (1978) and is called herein the 'Hoffman-Day' technique. This method is suitable for the analysis of NRMs consisting of three non-coplanar components which display partially overlapping blocking temperature spectra such that in lower temperatures components $\mathrm{L}$ and $\mathrm{I}$ are removed simultaneously, whereas in higher temperatures $I$ and $H$ are removed at the same time. This method enabled us to determine the I component for two sites in which $\mathrm{L}$ and I overlapped significantly, as described in the subsection below. The third technique is based on the great-circle intersection method of Halls (1976), which enabled us to attempt a determination of the $\mathbf{H}$ direction. This method is also discussed in a separate subsection below.

\section{The Hofiman-Day analysis and the direction of the I component}

In this method, a fit to a set of successive remanence vectors is determined by the principal component method (Kirschvink 1980). If a given sample has three components which do not all lie in the same plane, but which show overlap between $L$ and $I$ in the lower temperatures, and between $\mathrm{I}$ and $\mathrm{H}$ in the higher temperatures, then the trajectories of the magnetization vector during demagetization treatment will show two successive but different best-fit planes. A number of volcanic and redbed specimens from two sites displayed multicomponent behaviour similar to the specimens of Fig. 3 discussed above, but their demagnetization trajectories were continuously curved (Fig. 4) as a result of continuous overlap between unblocking temperature spectra for the different components. While directions cannot be accurately determined from the Zijderveld diagrams for any of the individual components, the Hoffman-Day method of intersecting specimen demagnetization planes was used to try to solve for the direction of the intermediate component. Like the majority of the Fisset Brook specimens, the specimens from these two sites show successive remanence vectors above $350^{\circ} \mathrm{C}$ which define a single demagnetization plane, confirming that only the two higher $T_{\mathrm{ub}}$ components ( $\mathrm{I}$ and $\mathrm{H}$ ) are present above $350^{\circ} \mathrm{C}$. In addition, a low- $T_{\mathrm{ub}}$ demagnetization plane is identified

Figure 3. (Opposite) Orthogonal vector diagrams (Zijderveld 1967) and equal-area plots of stepwise thermal demagnetizations of (a) volcanics and (b) red siltstones in which the intermediate (I) component is isolated. All sample directions are plotted with respect to palaeohorizontal. In the orthogonal vector diagrams open (closed) symbols represent projections onto the north-south vertical (horizontal) plane; the treatment applied to samples in successive steps is indicated. The axes are labelled in units of $10^{-2} \mathrm{~A} \mathrm{~m}^{-1}$. In the equal-area plots only sample directions for steps above $300^{\circ} \mathrm{C}$ are shown; open (closed) symbols in the equal-area plots represent directions in the upper (lower) hemisphere. The great circle shown for each sample represents the best-fit plane (Kirschvink 1980) to the demagnetization trajectory above $300^{\circ} \mathrm{C}$; dashed (solid) lines represent projections onto the upper (lower) hemisphere. The trend of the great circle paths for each sample is shown by an arrow. 
Table 1. Site mean directions for the Fisset Brook 1-component. Site numbers correspond to those in Figure 1 . $n / n_{0}$ is the ratio of samples used in the statistical analysis to those thermally demagnetized. Dec and Inc are declination and inclination of the magnetic directions. 100 per cent unfolding is correction for simple tilt of the strata; 39 per cent unfolding represents a partial tilt correction that is explained in the text. $k$ and $\alpha_{9 s}$ are the precision parameter and the semiangle of the cone of 95 per cent confidence associated with the mean direction, respectively (Fisher, 1953). Dm and Im are declination and inclination of the overall mean direction.

\begin{tabular}{|c|c|c|c|c|c|c|c|c|c|c|}
\hline \multirow[b]{2}{*}{ Site } & \multirow[b]{2}{*}{$n / n_{0}$} & \multirow{2}{*}{$\begin{array}{l}\text { Bedding } \\
\text { Strike/Dip } \\
\text { deg }\end{array}$} & \multicolumn{2}{|c|}{ In situ } & \multicolumn{2}{|c|}{$\begin{array}{l}\text { After } 100 \text { per cent } \\
\text { Unfolding }\end{array}$} & \multirow[b]{2}{*}{$k$} & \multirow[b]{2}{*}{$\begin{array}{l}\alpha_{95} \\
\operatorname{deg}\end{array}$} & \multicolumn{2}{|c|}{$\begin{array}{l}\text { After } 39 \text { per cent } \\
\text { Unfolding }\end{array}$} \\
\hline & & & $\begin{array}{l}\text { Dec } \\
\text { deg }\end{array}$ & $\begin{array}{l}\text { Inc } \\
\text { deg }\end{array}$ & $\begin{array}{l}\text { Dec } \\
\text { deg }\end{array}$ & $\begin{array}{l}\text { Inc } \\
\text { deg }\end{array}$ & & & $\begin{array}{l}\text { Dec } \\
\text { deg }\end{array}$ & $\begin{array}{l}\text { Inc } \\
\text { deg }\end{array}$ \\
\hline $1 R$ & $4 / 5$ & $167 / 24$ & 155 & 33 & 171 & 35 & 51.1 & 13.0 & 161 & 34 \\
\hline $1 \mathbf{R}^{\prime}$ & $1 / 2$ & $167 / 24$ & 161 & 30 & 175 & 30 & - & - & 166 & 31 \\
\hline${ }^{*} 2 \mathrm{~V}$ & $6 / 6$ & $167 / 24$ & 163 & 37 & 181 & 35 & 80.4 & 7.5 & 170 & 37 \\
\hline $3 \mathbf{R}$ & $3 / 4$ & $167 / 24$ & 155 & 34 & 172 & 36 & 34.4 & 21.1 & 161 & 35 \\
\hline $3 \mathrm{~V}$ & $0 / 4$ & $167 / 24$ & - & - & - & - & - & - & - & - \\
\hline$* 4 R$ & $4 / 5$ & $40 / 12$ & 166 & 50 & 159 & 40 & 136.4 & 7.9 & 163 & 46 \\
\hline $4 \mathrm{~V}$ & $3 / 4$ & $40 / 12$ & 173 & 49 & 166 & 40 & 88.9 & 13.2 & 170 & 45 \\
\hline $5 \mathbf{R}$ & $4 / 8$ & $264 / 41$ & 154 & 16 & 140 & 53 & 48.8 & 13.3 & 151 & 31 \\
\hline $6 \mathrm{~V}$ & $5 / 6$ & $269 / 50$ & 164 & 22 & 140 & 68 & 54.1 & 10.5 & 161 & 41 \\
\hline $7 \mathrm{R}$ & $4 / 4$ & $269 / 50$ & 153 & 26 & 115 & 64 & 80.5 & 10.3 & 146 & 43 \\
\hline $7 \mathrm{~V}$ & $3 / 5$ & $269 / 50$ & 157 & 14 & 136 & 58 & 45.0 & 18.6 & 154 & 32 \\
\hline \multicolumn{11}{|c|}{10 sites): } \\
\hline \multirow{2}{*}{\multicolumn{3}{|c|}{$\begin{array}{l}\text { in situ } \\
39 \text { per cent unfolding }\end{array}$}} & $\mathrm{Dm}=160^{\circ}$ & \multicolumn{3}{|c|}{$\operatorname{Im}=31^{\circ}$} & 37.2 & $8.0^{\circ}$ & & \\
\hline & & & $\mathrm{Dm}=160^{\circ}$ & \multirow{2}{*}{\multicolumn{3}{|c|}{$\begin{array}{l}\operatorname{Im}=38^{\circ} \\
\operatorname{Im}=47^{\circ}\end{array}$}} & 90.8 & $5.1^{\circ}$ & & \\
\hline \multicolumn{3}{|c|}{100 per cent unfolding } & $\mathrm{Dm}=161^{\circ}$, & & & & 17.9 & $11.7^{\circ}$ & & \\
\hline
\end{tabular}

a The direction of bedding dip is $90^{\circ}$ clockwise from the strike direction.

* The I-component direction in individual samples from these sites corresponds to the intersection of low-temperature and high-temperature demagnetization planes (Hoffman-Day directions) (Kirschvink, 1980).

for each specimen, as defined by the remanence vectors between the NRM and $350^{\circ} \mathrm{C}$, in which only the $\mathrm{L}$ and $\mathrm{I}$ components are removed. For the specimens in Fig. 4, the low- $T_{\text {ub }}$ demagnetization planes trend approximately from the present-day field direction (shown corrected for geological tilt in Fig. 4) toward the southeast. In most of the specimens the low- $T_{\mathrm{ub}}$ and high- $T_{\mathrm{ub}}$ demagnetization planes intersect in a southeasterly direction (e.g. Fig. 4), which is taken to be the direction of the intermediate component of magnetization (I). The directions found for this I component from the intersections of the demagnetization planes agree very well with those determined for I from the analysis of demagnetization lines. In Table 1 all $I$ directions are grouped together to yield an overall mean I direction. It is noted that site $3 \mathrm{~V}$ was the only site at which it was not possible to resolve the I component. While the volcanic specimens from this site yielded curved demagnetization trajectories, the successive remanence vectors for specimens during demagnetization were approximately coplanar, thus preventing identification of separate low- $T_{\mathrm{ub}}$ and high- $T_{\mathrm{ub}}$ demagnetization planes.

The site means for the intermediate (I) component (Table 1) are shown on equal-area plots in Fig. 5, along with the sample directions. It is noted that in situ site means all have fairly uniform south-southeasterly declinations; however, their inclinations vary from $+10^{\circ}$ to $+50^{\circ}$ and the resultant streaked distribution of in situ site means is non-Fisherian (Fig. 5a). Rather than reducing the scatter, application of a simple tilt correction causes increased dispersion in the site mean directions (Fig. 5b). The distribution of tilt-corrected site means is similarly non-Fisherian, showing a considerable variation in inclination as well as declination. As might be expected, a standard fold test (McElhinny 1964) for the I component is inconclusive because the precision parameters $(k)$ for site means before $\left(k_{1}\right)$ and after tilt correction $\left(k_{2}\right)$ are not significantly different from one another (Table 1$)$.

The non-Fisherian distributions of in situ and tiltcorrected site means for the I component could be explained by: (1) systematic deflection of site means caused by undetected overlap between multiple vectorial components, or (2) the existence of a complexity in the structural tilt history such that simple tilt correction does not restore the strata to the configuration in which the I component was acquired. Although it is not possible a priori to rule out the first hypothesis, it is noted that site means for both volcanics and redbeds from the same locality, having the same structural attitude, group well together, whereas the greatest variation in site mean directions exists between localities having different structural orientations (envelopes Fig. 5). This evidence tends to support the second hypothesis. It is noted that simple vertical axis rotations between localities are precluded because they cannot explain the variation in site mean inclinations, either in situ or after tilt correction. On the other hand, the site means from localities having different structural attitudes appear to cross near a common direction during correction for bedding tilt. This relationship is particularly evident in the comparison of means from sites 1-4, which have fairly mild dips, with those from the western localities (sites 5-7), which have much stronger tilt corrections: the means for sites 1-4 do not move much during tilt correction, yet they lie close to the small circle between the in situ and tilt-corrected (100 per cent 

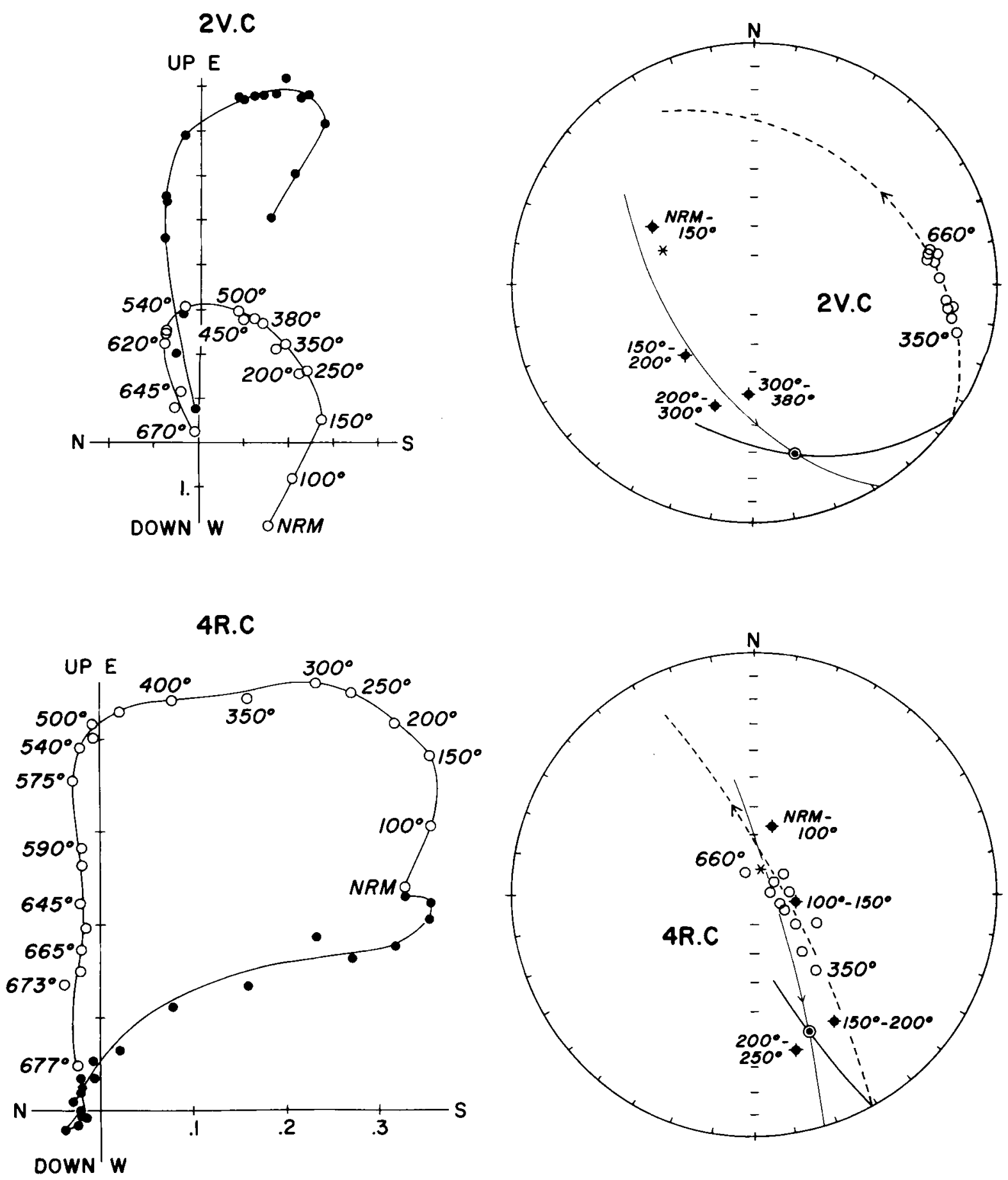

Figure 4. Orthogonal vector diagrams and equal-area plots of thermal demagnetizations of samples having multivectorial components with overlapping unblocking temperatures. The plotting conventions used are the same as in Fig. 3. Sample directions for steps above $300{ }^{\circ} \mathrm{C}$, and the corresponding best-fit (high-temperature) demagnetization plane are shown in the accompanying equal-area plots for each sample (heavy line). In addition, the best-fit plane to the demagnetization trajectory for steps below $300^{\circ} \mathrm{C}$ is shown in the equal-area plot for each sample (low-temperature demagnetization plane; thin line). The intersection of low-temperature and high-temperature demagnetization planes, marked by a circle with a dot in the centre, is interpreted as the direction for the intermediate (I) component in these samples. The directions for subtracted vectors (solid circles with crosses), identified in the diagram, indicate that these vectors lie approximately within the low-temperature demagnetization planes, as expected. The low-temperature demagnetization planes trend away from the present-day field direction which is corrected for geological tilt and represented by an asterisk in each of the equal-area plots. 
a)
IN SITU

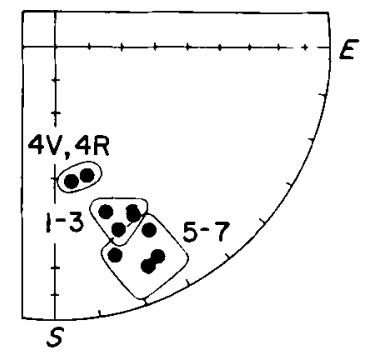

b) $100 \%$ UNFOLDING
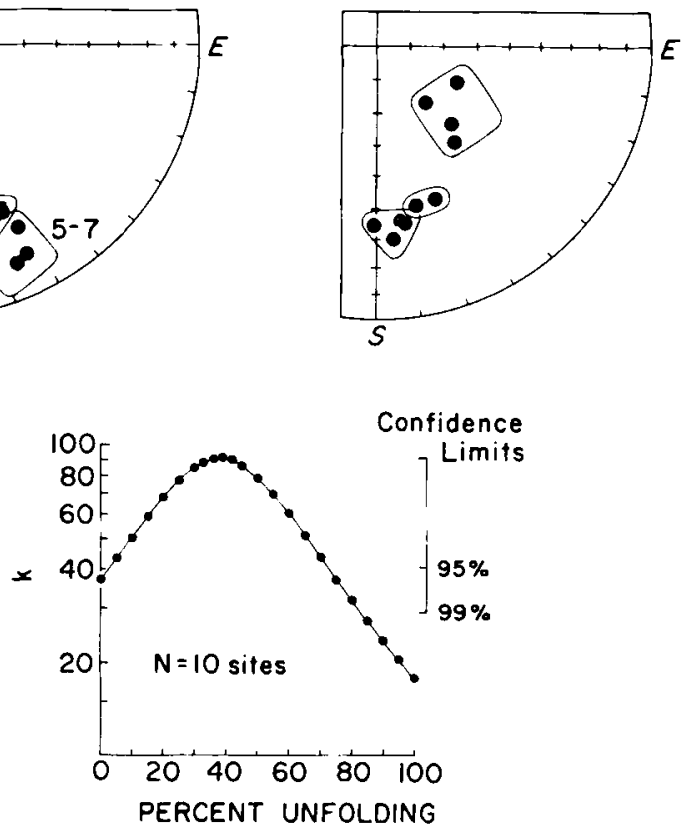

c)

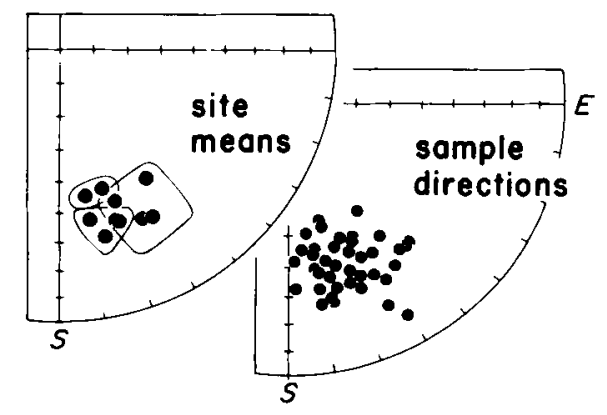

Figure 5. Site mean directions for the I component plotted (a) in situ and (b) after 100 per cent unfolding (simple tilt correction), and (c) site means as well as sample directions shown after 39 per cent of the tilt correction is applied. A plot of the logarithm of the precision parameter $k$ versus per cent unfolding is also shown; the peak value $(k=90.8)$ occurs at 39 per cent unfolding. In the equal-area plots, closed (open) symbols represent directions in the lower (upper) hemisphere. Also, in the equal-area plots, groups of sites having the same or similar (in the case of sites 5-7) tilt corrections are outlined to show the effects of the fold test; the sites are labeled in (a), and the same envelopes are shown in (b) and (c).

unfolding) directions for sites 5-7. This relationship between site mean directions for the I component leads us to suspect that this component may be of synfolding origin (e.g. Scotese 1985; Kent \& Opdyke 1985). In order to test this possibility, an incremental fold test was performed, consisting of the calculation of the overall means and precision parameters (Fisher 1953) for successive distributions of the site means resulting from applying a partial tilt correction to each site, and progressively increasing the tilt correction by discrete percentage increments from 0 per cent (in situ) to 100 per cent (fully tilt-corrected). The results of this procedure for the I component are shown in Fig. 5. The precision parameter, $k$, for the site means varies systematically with the per cent unfolding, revealing a maximum value when 39 per cent of the total tilt correction is applied to each site (Fig. 5). The increase in $k$ for a 39 per cent tilt correction is significant at the 95 per cent confidence level compared to the values of $k$ in situ $(0$ per cent unfolding) and after full tilt correction ( 100 per cent unfolding). The significantly better grouping of the site means after only partial tilt correction, as well as their approximately Fisherian distribution (Fig. 5c), implies that the I component is of synfolding, hence secondary, origin. The overall mean for the I component after 39 per cent unfolding is $D=160^{\circ}, l=+38^{\circ}, k=90.8, \alpha_{95}=5.1^{\circ}$.

\section{Great-circle intersections and the direction of the $\mathbf{H}$ component}

In order to determine the $\mathrm{H}$ direction, the high-temperature demagnetization planes of all samples such as shown in Figs 3 and 4 were analysed with the method of Halls (1976). Great circles defined by the $I$ and $H$ components for specimens or samples from the same site are generally parallel, but as seen from the figures the great circles followed by specimens from different sites have different orientations. The differently trending great circles allow us to determine the best-fit intersection, which is the best estimate of the direction common to all planes. In general, successful application of the method of intersecting great circles (demagnetization planes) requires that the two components involved have significantly different dispersions: the great circles will thus tend to intersect in the direction of the component with lower dispersion. In comparing great circles from different sites in folded strata, such as is the case for the Fisset Brook Formation, it is particularly hoped that the two components were acquired at different times relative to the folding, such that the tilt correction increases the dispersion in one component while decreasing the dispersion in the other. Using the algorithm of Bailey \& Halls (1984) it is possible to estimate the Fisherian statistics (including the precision parameter, $k$ ) for the underlying distribution of magnetization directions that give rise to an intersection. This availability of $k$ thus allows us to perform an incremental fold test using great circles.

Site mean great circles have been used for a between-site comparison, and the poles to these planes, corresponding to the Fisherian mean of poles to individual sample great circles for each site, are shown on equal-area plots in Fig. 6 (see also Table 2), along with the total population of poles to the sample great circles. The results of the incremental fold test using these site mean great circles are also presented in Fig. 6. The poles to site mean great circles yield slightly different WSW to ENE trending girdle distributions throughout the unfolding procedure (Fig. 6). For each increment of unfolding, the 'best-fit' solution for the intersection of the great circles is a direction trending generally NNW with an inclination ranging from $-30^{\circ}$ to $-40^{\circ}$. The $k$ versus per cent unfolding curve for the intersection of great circles (Fig. 6) reveals a simple variation in which a single maximum occurs when 60 per cent of the total tilt correction is applied to each site. The increase in $k$ at 60 per cent unfolding is significant at the 95 per cent confidence level (but not at the 99 per cent level) compared to $k$ for the in situ distribution and the 
a)

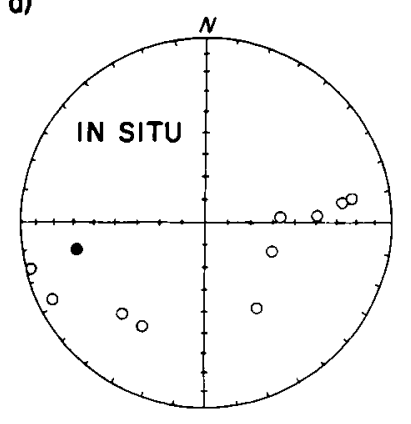

b)

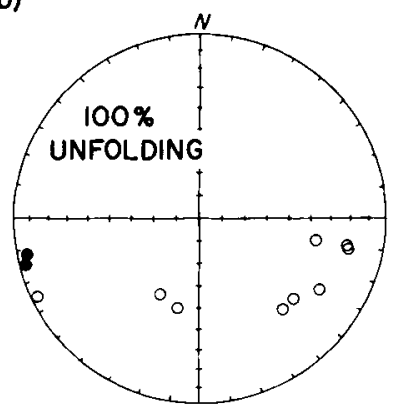

c)

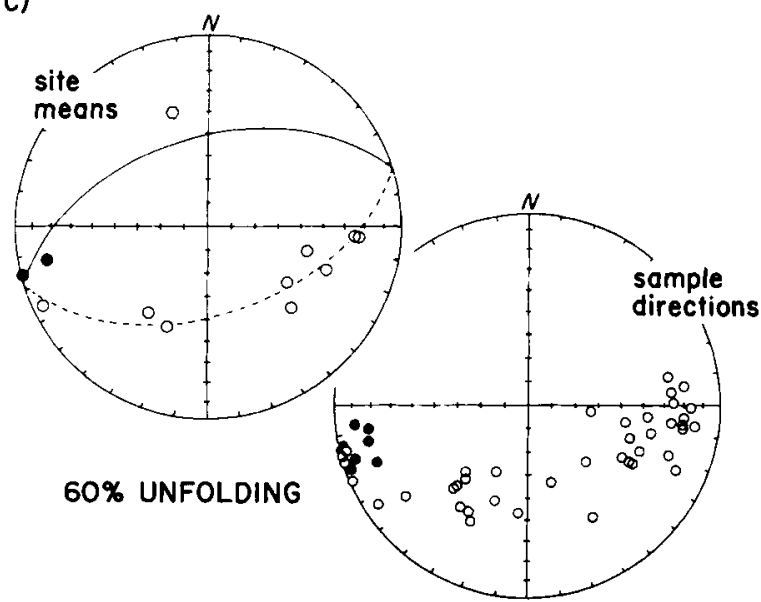

)

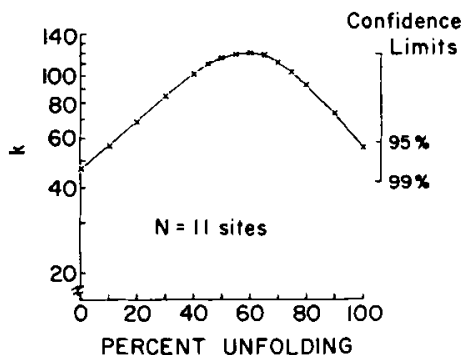

idence

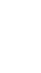

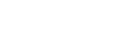

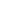


distribution with full tilt correction. The direction for 'best-fit' intersection of great circles after 60 per cent unfolding is $D=342^{\circ}, I=-38^{\circ}, k=120.9, \alpha_{95}=6.9^{\circ}$.

The interpretation of the incremental fold test for the great circles is ambiguous. While it implies that at least one of the components (defining the site mean great circles) is of synfolding origin, the resultant intersection could correspond to either the I or the $\mathrm{H}$ component, or both, if they happen to be antiparallel directions. Despite this uncertainty we note that the presence of antiparallel directions is consistent with the trends of demagnetization trajectories in the majority of Fisset Brook samples, which move from the southern toward the northern hemisphere. Moreover, the nearly complete girdle distribution of the poles to great circles from different sites is typical of antipodal directions, whereas in the case of non-antipodal directions the connecting great circles (defined by the vector sums of the two components in various proportions) would all follow the same path. We therefore believe that in our case both $I$ and $\mathrm{H}$ are synfolding and that they are antiparallel. We note, furthermore, that this interpretation is the most conservative

a)

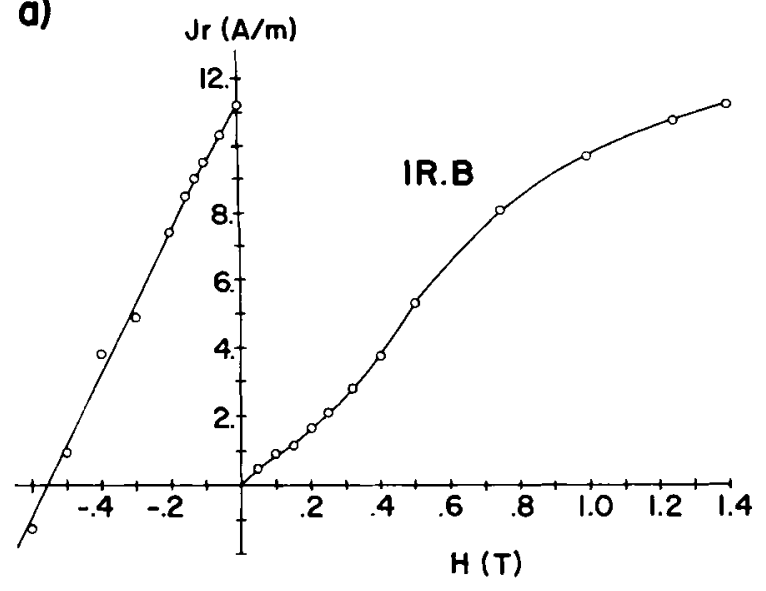

c)

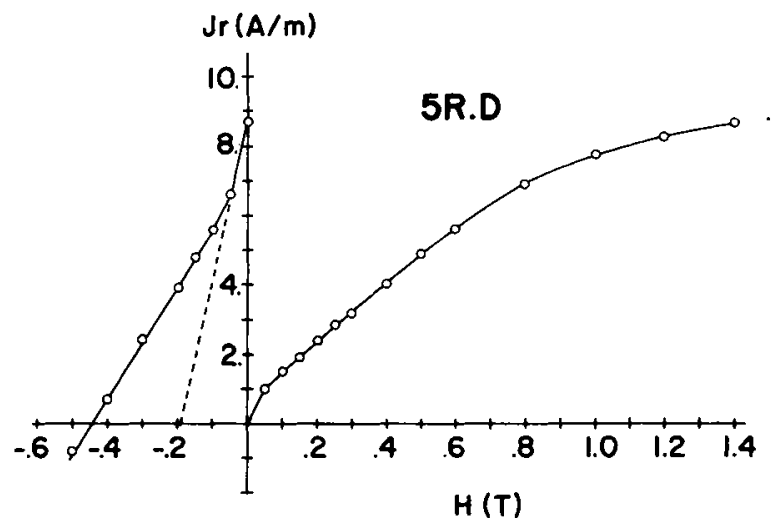

in terms of the age of the $\mathrm{I}$ and $\mathrm{H}$ components and is least likely to introduce erroneously interpreted poles to the literature.

\section{IDENTIFICATION OF MAGNETIC MINERALS}

The magnetic minerals present in the volcanics and redbeds were investigated using isothermal remanent magnetization (IRM) techniques, and by microscopic examination of polished sections in reflected light. The acquisition of IRM, and backfield IRM, of a number of unheated redbed and volcanic specimens were investigated, and typical results for each rock type are shown in Fig. 7. The IRM acquisition curves for the redbeds (Fig. 7a,b,c) indicate that they generally do not saturate in fields of approximately 1.4 Tesla (T), while the corresponding backfield curves indicate coercivities $(\mathrm{Hcr})$ of between $0.4 \mathrm{~T}$ and $0.6 \mathrm{~T}$ (Fig. 7a). The IRM behaviour exhibited by the redbeds is typical of haematite (e.g. Dankers 1981), which is also suggested by the maximum unblocking temperatures observed for the

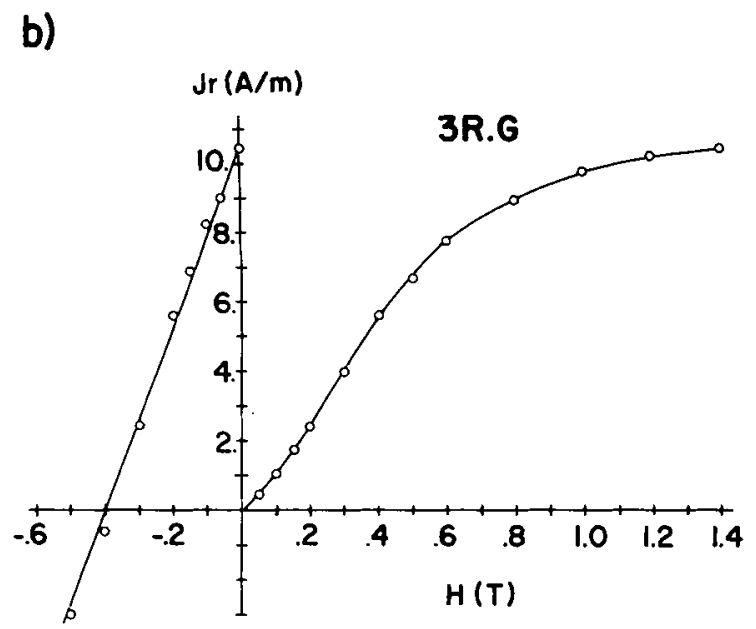

d)

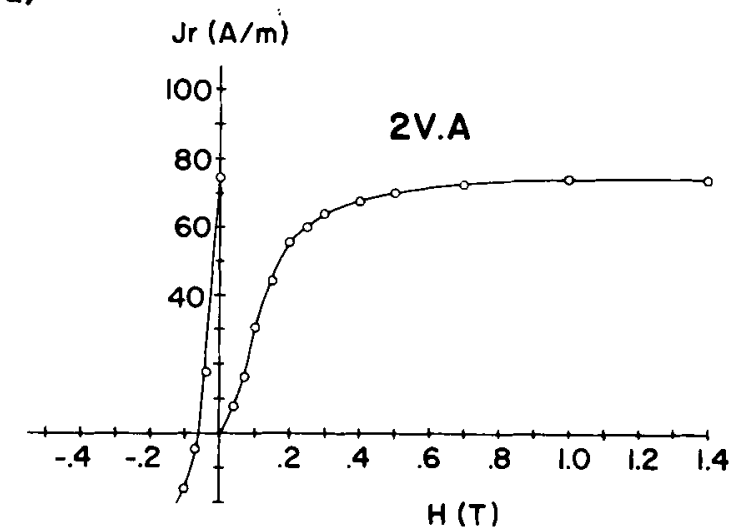

Figure 7. Isothermal remanent magnetization (IRM) acquisition and backfield IRM curves for specimens of (a)-(c) red siltstone and (d) volcanics. $\mathrm{H}$ is the intensity of the magnetic field applied to samples (at $20^{\circ} \mathrm{C}$ ) in either a positive or negative (backfield) direction; $J_{\mathrm{r}}$ is the remanence intensity with corresponding positive or negative direction. The remanent coercivity (Hcr) for a given specimen is estimated as the intersection of its backfield curve with the horizontal axis; the initial slope of the backfield curve in (c) was projected onto the horizontal axis (dotted line) in order to estimate $\cdot$ Her for the low coercivity component in this specimen. 
NRM in this rock type. The rapid initial acquistion of IRM in a few redbed specimens (e.g. Fig. 7c), however, indicates the presence of a low-coercivity carrier in addition to haematite. The coercivity (Hcr) of this carrier in Fig. 7c is estimated from the initial slope of the backfield curve to be about $0.2 \mathrm{~T}$, which is in the range usually observed for magnetite $(\mathrm{Hcr} \leq 0.3 \mathrm{~T})$. We thus infer that a small amount of detrital magnetite may be present in some redbed samples. The IRM behaviour of the volcanic specimens (e.g. Fig. 7d) was very uniform. In contrast to the redbeds, they reveal an order of magnitude stronger saturation IRM (sIRM) intensities, and acquire a significant fraction (>85 per cent) of their sIRM in applied fields of less than $0.3 \mathrm{~T}$. The low-coercivity component generally dominates the backfield curves for the volcanics, indicating coercivities of approximately $0.06 \mathrm{~T}$. These coercivities as well as the higher sIRM intensities indicate the presence of magnetite. Nonetheless, the additional presence of haematite is documented by the fact that the volcanic specimens do not totally saturate until fields of $1.0 \mathrm{~T}$ (Fig. 7d). Furthermore, unblocking temperatures observed during thermal demagnetization of volcanic specimens indicate haematite as a magnetic carrier as well. While most of the IRM intensity in the volcanics is carried by the low-coercivity component, we note that the IRM intensity acquired by volcanic specimens between 0.3 and $1.4 \mathrm{~T}$, presumably carried by haematite, is similar in magnitude to the sIRM of the redbeds.

Polished sections were made from a number of the IRM samples and these were studied at magnifications up to $400 \times$. The redbeds examined were composed, on average, of 75 per cent detrital grains and 25 per cent interstitial fine-grained red-brown haematite. A minor calcite cement is also present in most samples. The detrital grains are predominantly quartz but they include 2-3 per cent each of plagioclase and opaques. All of the detrital grains are about the same size ( $30-50 \mu \mathrm{m}$ diameter), and although they were probably originally subrounded they now display extremely irregular and embayed boundaries. The detrital opaques are almost all (titano)magnetites; however, these are altered to dark-coloured fine-grained haematite around their margins, and in many cases haematite occupies up to 50 per cent of the volume of individual opaque grains. It is interesting to note, however, that the (titano)magnetites are less altered along margins where they abut against other detrital grains (e.g. quartz), whereas replacement haematite forms large embayments in such grains adjacent to original interstices. This textural evidence suggests that the haematite-replacing (titano)magnetites formed in situ, during diagenesis. The fact that the replacement haematite is easily removed during polishing, and thus is quite soft, supports this interpretation since it is unlikely that this material could have survived detrital transport. In view of the fact that the interstititial haematite and calcite cement commonly occupy large embayments in detrital quartz grains, both of these components are inferred to be secondary as well.

Opaques are relatively abundant in the volcanics, comprising about 10 per cent by volume. They include approximately equal proportions of elongate (length to width ratio of $5: 1$ ) ilmenite grains and equant-shaped (titano)magnetites, although many of the latter grains are partially to completely altered to haematite. The (titano)magnetites have diameters ranging from 15 to
$150 \mu \mathrm{m}$ and, except for a few completely altered grains, they display subhedral to euhedral textures, indicating a primary origin. Haematite occurs as irregular patches within the (titano)magnetite grains, occupying anywhere from $<5$ to $>90$ per cent of the volume of the host grain. While the degree of alteration typically varies between grains in a given sample, haematite replaces at least half of the total magnetite originally present in every one of the samples studied.

\section{INTERPRETATION OF RESULTS}

Based on the unblocking temperatures observed for the I and $H$ components in the redbeds, as well as on their rock magnetic and petrographic properties, it is inferred that both components in this rock type are carried entirely by haematite. Although detrital magnetites are found in many of the redbed specimens, because of their large grain sizes they are probably multidomain grains and are therefore unlikely to carry a stable ancient remanence, whether primary or secondary. In view of the secondary origin of the $\mathrm{I}$ and $\mathrm{H}$ components in the redbeds, and the extremely high burial temperatures required to thermally reset haematite grains with such high unblocking temperatures (e.g. Pullaiah et al. 1976), both components are probably chemical remanent magnetizations (CRMs) resulting from haematite grown in situ. Abundant secondary (authigenic) haematite is clearly present in the redbeds, including the interstitial haematite and the haematite replacing detrital (titano)magnetites, and both forms are possible carriers of the I and $\mathrm{H}$ components. The presence of dual-polarity directions in the redbeds indicates that the CRM process occurred during a period of polarity transitions of the palaeomagnetic field, and that it spanned at least one polarity transition.

The $I$ and $H$ components in the volcanics have unblocking temperature spectra similar to those observed in the redbeds, suggesting that haematite carries these components in the volcanics as well. As in the case of the redbeds, the relict magnetite grains in the volcanics are probably too large to carry a stable ancient remanence. The $I$ and $H$ components in the volcanics are inferred to be secondary CRMs, presumably carried by the haematite that replaced the original (titano)magnetites.

The inferred synfolding timing of acquisition of the I and $H$ components constrains their ages to lie between the times of the initiation and final completion of tilting of the Fisset Brook Formation. Given that this unit was affected by two distinct episodes of tilting in Late Tournaisian and Mid-Namurian times, respectively, the $\mathrm{I}$ and $\mathrm{H}$ components could have been acquired any time within the intervening interval. These components of magnetization are thus considered to be late Early Carboniferous in age.

The magnetizations observed in the Fisset Brook strata are similar to dual-polarity, post-depositional magnetizations reported previously for other redbed units (e.g. Roy \& Morris 1983). Based on the widespread occurrence of such magnetizations in redbeds, it has been suggested that their magnetization is typically a long process involving the progressive alteration of the host rock and formation of authigenic haematite under generally oxidizing burial conditions (e.g. Walker, Larson \& Hoblitt 1981; Larson et al. 1982). Our results for the Fisset Brook Formation are 
consistent with this model. Although not documented previously, volcanics interbedded with redbeds would probably be at least partially oxidized under such conditions, and this process could explain the contemporaneous acquisition of secondary CRM in the Fisset Brook volcanics as well. That volcanic rocks apparently can acquire a post-depositional CRM of this nature is noteworthy, and should serve as a warning to investigators working on such rocks in other areas, particularly where field tests are not available.

\section{COMPARISON OF CARBONIFEROUS PALAEOMAGNETIC DATA FROM THE NORTHERN APPALACHIANS AND CRATONIC NORTH AMERICA}

The I component directions reported in Table 1 are assumed to record the reverse (south) polarity paleomagnetic field relative to northern Cape Breton Island. The mean for the I component yields a corresponding normal polarity palaeopole of $20^{\circ} \mathrm{N}, 138^{\circ} \mathrm{E}\left(d p=4^{\circ}, d m=6^{\circ}\right)$, and a palaeolatitude for the study area of $21 \pm 4^{\circ} \mathrm{S}$. The direction for the $\mathrm{H}$ component, corresponding to the best-fit intersection of great circles, is antipodal to that of the I direction. The resulting palaeopole is nearly identical to that for the I component, but the uncertainties in the direction and the palaeopole position determined by this method are slightly greater (compare Tables 1 and 2). Given that the direct observations of the vector-subtracted I component and the $\mathbf{H}$ direction obtained from great-circle intersections are derived from the same samples, their directions are not

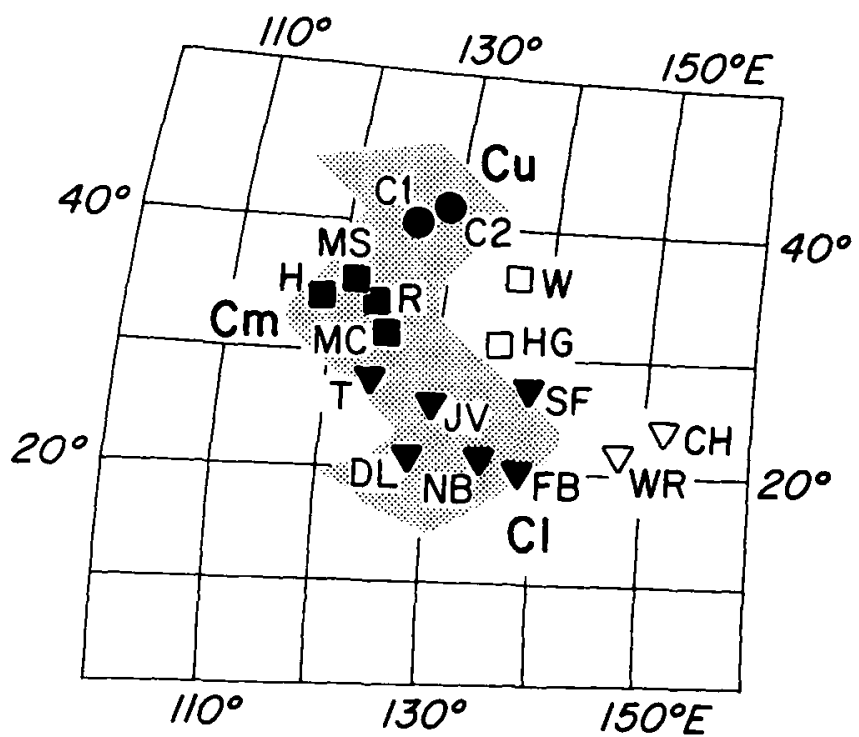

Figure 9. Carboniferous palaeomagnetic poles from the northern Appalachians and cratonic $\mathbf{N}$ America. Early Carboniferous (Tournaisian-Early Namurian) poles are represented by triangles; Mid-Carboniferous (Late Namurian or Early Westphalian) poles are represented by squares; Late Carboniferous (Late WestphalianStephanian or Late Pennsylvanian) poles are represented by circles. The individual poles are identified by their letter symbol in Table 3. The poles from the Meguma terrain are represented by open symbols, all other poles are shown by solid symbols. The shaded region represents the inferred Carboniferous apparent polar wander path for $\mathbf{N}$ America including the northern Appalachians, except for the Meguma terrain which was rotated counter-clockwise with respect to the craton in the Late Carboniferous.

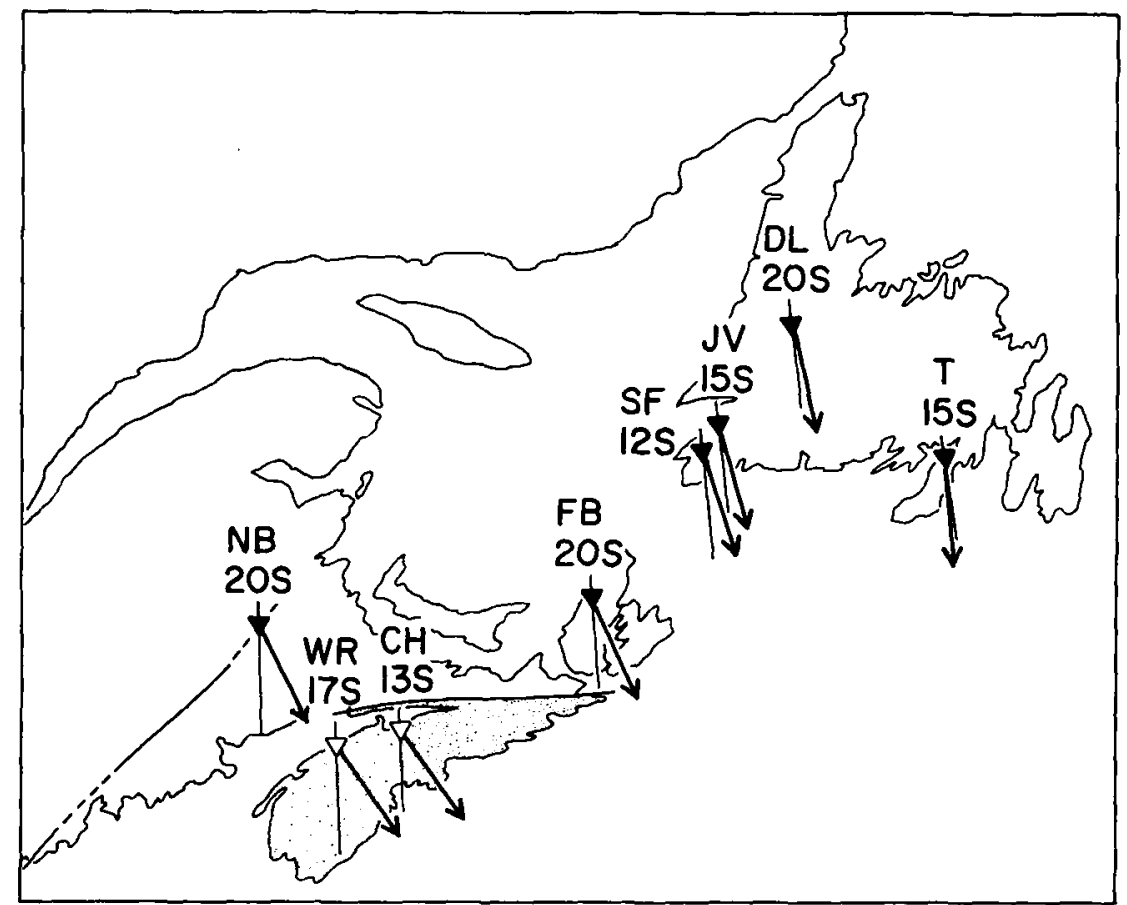

Figure 8. Palaeolatitudes and declinations from Early Carboniferous (Tournaisian-Early Namurian) palaeomagnetic results from the northern Appalachians. The individual results shown are identified in Table 3 according to their letter symbol. The Early Carboniferous declinations from the Meguma terrain (shaded in the figure) are rotated relative to other results from the northern Appalachians (e.g. Spariosu et al. 1984). 
Table 3. Carboniferous palaeomagnetic poles from Maritime Canada and cratonic North America after Murthy (1985). Key is the symbol used to identify individual poles in Figures 8 and 9. For those rock units containing more than one component of magnetization, the component corresponding to the palaeopole is identified. Plat. and Plon. are the latitude and longitude of the palaeomagnetic pole. $A_{95}$ is the semiangle of the circle of 95 per cent confidence associated with the mean pole (McElhinny, 1973). $\Phi$ is the palaeolatitude predicted for the study area in Cape Breton Island (46.6N, 299.0E). A few poles listed by Murthy (1985) have not been included here and the reasons for their exclusion are as follows: the Sprout Falls B and Searston A poles have not been included because they were derived from low blocking temperature magnetizations which we believe may be contaminated with PEF components; the Searston C pole, as well as palacopoles for the St. Lawrence pluton, the Lilesville pluton and the Austell gneiss, are excluded because of their uncertain ages.

\begin{tabular}{|c|c|c|c|c|c|c|}
\hline & Key & Rock unit (Component) & $\begin{array}{l}\text { Plat., Plon. } \\
\text { deg }\end{array}$ & $\begin{array}{l}A_{95} \\
\text { deg }\end{array}$ & $\begin{array}{l}\Phi \\
\mathrm{deg}\end{array}$ & Reference \\
\hline \multicolumn{7}{|c|}{ Late Carboniferous } \\
\hline \multicolumn{7}{|c|}{ Maritime Canada } \\
\hline 1. & & Deer Lake $(\mathrm{H})$ & $45 \mathrm{~N}, 140 \mathrm{E}$ & & $4 N$ & Irving and Strong (1984) \\
\hline 2. & & Terrenceville (B) & $44 \mathrm{~N}, 117 \mathrm{E}$ & & $1 \mathrm{~N}$ & Kent (1982) \\
\hline 3. & & Spanish Room Fm. & $47 \mathrm{~N}, 129 \mathrm{E}$ & & $4 N$ & Irving and Strong (1985) \\
\hline 4. & & P.E.I. red beds & $42 \mathrm{~N}, 133 \mathrm{E}$ & & is & Roy (1966) \\
\hline 5. & & Tormentine Fm. & $41 \mathrm{~N}, 132 \mathrm{E}$ & & $2 S$ & Roy (1966) \\
\hline 6. & & Morien Group & $40 \mathrm{~N}, 131 \mathrm{E}$ & & $3 \mathrm{~S}$ & Scotese et al. (1984) \\
\hline 7. & & Bonaventure Fm. & $38 \mathrm{~N}, 133 \mathrm{E}$ & & $5 S$ & Roy (1966) \\
\hline 8. & & Hurley Creek Fm. & $39 \mathrm{~N}, 125 \mathrm{E}$ & & $4 S$ & Roy et al. (1968) \\
\hline 9. & & Cumberland Group & $36 \mathrm{~N}, 125 \mathrm{E}$ & & $7 S$ & Roy (1969) \\
\hline & $\mathrm{C} 1$ & Mean Pole (\#'s 1-9): & $42 \mathrm{~N}, 129 \mathrm{E}$ & 3.8 & 1S & \\
\hline & \multicolumn{6}{|c|}{ Cratonic North America } \\
\hline 1. & & Casper Fm. & $46 \mathrm{~N}, 129 \mathrm{E}$ & & $3 \mathrm{~N}$ & Diehl and Shive (1981) \\
\hline 2. & & Buffalo siltstone & $27 \mathrm{~N}, 123 \mathrm{E}$ & & $16 S$ & Payne et al. (1981) \\
\hline 3. & & Brush Creek Lst. & $36 \mathrm{~N}, 124 \mathrm{E}$ & & $7 S$ & Payne et al. (1981) \\
\hline 4. & & Bonneterre Fm. $^{\mathbf{a}}$ & $43 \mathrm{~N}, 126 \mathrm{E}$ & & 0 & Wisniowiecki et al. (1983) \\
\hline 5. & & St. Joe Lst. ${ }^{\mathrm{a}}$ & $39 \mathrm{~N}, 132 \mathrm{E}$ & & $4 S$ & Scott (1979) \\
\hline 6. & & Barnett Fm. & $49 \mathrm{~N}, 119 \mathrm{E}$ & & $5 \mathrm{~N}$ & Kent and Ópdyke (1979) \\
\hline 7. & & Red Mountain Fm. ${ }^{a}$ & $38 \mathrm{~N}, 132 \mathrm{E}$ & & $5 S$ & Perroud and Van der Voo (1984) \\
\hline & $\mathrm{C} 2$ & Mean Pole (\#'s 1-7): & $40 \mathrm{~N}, 127 \mathrm{E}$ & 6.1 & $3 S$ & \\
\hline \multicolumn{7}{|c|}{ Middle Carboniferous } \\
\hline \multicolumn{7}{|c|}{ Maritime Canada } \\
\hline 1. & $\mathbf{H}$ & Hopewell Group & $34 \mathrm{~N}, 118 \mathrm{E}$ & & $9 S$ & Roy and Park (1969) \\
\hline 2. & $\mathbf{R}$ & Riversdale Group & $34 \mathrm{~N}, 124 \mathrm{E}$ & & $9 \mathrm{~S}$ & Roy (1977) \\
\hline 3. & MS & $\begin{array}{l}\text { Maringouin and } \\
\text { Shepody Fms. }\end{array}$ & $36 \mathrm{~N}, 122 \mathrm{E}$ & & $7 S$ & Roy and Park (1974) \\
\hline 4. & $\mathbf{w}$ & Windsor Group ${ }^{b}$ & $36 \mathrm{~N}, 137 \mathrm{E}$ & & - & Scotese et al. (1984) \\
\hline \multirow[t]{2}{*}{5.} & HG & Horton Group ${ }^{b}$ & $32 \mathrm{~N}, 136 \mathrm{E}$ & & - & Scotese et al. (1984) \\
\hline & & Mean Pole (\#'s 1-3): & $35 \mathrm{~N}, 121 \mathrm{E}$ & 4.2 & $8 S$ & \\
\hline 1. & MC & $\begin{array}{l}\text { Cratonic North America } \\
\text { Mauch Chunk Fm. }\end{array}$ & $31 \mathrm{~N}, 125 \mathrm{E}$ & & $12 S$ & Kent and Opdyke (1985) \\
\hline \multicolumn{7}{|c|}{ Early Carboniferous } \\
\hline \multicolumn{7}{|c|}{ Maritime Canada } \\
\hline 1. & JV & Jeffreys Village (A) & $27 \mathrm{~N}, 131 \mathrm{E}$ & & $16 S$ & Murthy (1985) \\
\hline 2. & DL & $\begin{array}{l}\text { Deer Lake Group } \\
(\mathrm{N}, \mathrm{S})\end{array}$ & $21 \mathrm{~N}, 128 \mathrm{E}$ & & $22 S$ & Irving and Strong (1984) \\
\hline 3. & $\mathbf{T}$ & Terrenceville (A) & $27 \mathrm{~N}, 124 \mathrm{E}$ & & $16 S$ & Kent (1982) \\
\hline 4. & SF & Sprout Falls (A) & $29 \mathrm{~N}, 140 \mathrm{E}$ & & $13 S$ & Murthy (1985) \\
\hline 5. & FB & Fisset Brook (I) & $20 \mathrm{~N}, 139 \mathrm{E}$ & & $21 S$ & This study \\
\hline 6. & NB & $\begin{array}{l}\text { New Brunswick } \\
\text { volcanics and } \\
\text { red beds }\end{array}$ & $21 \mathrm{~N}, 135 \mathrm{E}$ & & $21 \mathrm{~S}$ & Seguin et al. (1985) \\
\hline \multirow{3}{*}{$\begin{array}{l}7 . \\
8 .\end{array}$} & $\mathrm{CH}$ & Cheverie Fm. & $24 \mathrm{~N}, 152 \mathrm{E}$ & & - & Spariosu et al. (1984) \\
\hline & WR & White Rock Fm. ${ }^{b}$ & $22 \mathrm{~N}, 148 \mathrm{E}$ & & - & Spariosu et al. (1984) \\
\hline & & Mean Pole (\#'s 1-6): & $24 \mathrm{~N}, 133 \mathrm{E}$ & 5.8 & $18 S$ & \\
\hline
\end{tabular}

\footnotetext{
${ }^{a}$ These rock units from the craton are considered to have been remagnetized in Late Carboniferous-Early Permian (Kiaman) time (e.g. Roy and Morris, 1983; Murthy 1985; Van der Voo, 1988).

b These poles from the Meguma terrain are probably rotated relative to the Carboniferous poles from Maritime Canada and cratonic North America; based on their displacement relative to the other Meguma poles we believe, furthermore, that the Horton (HG) and Windsor (W) poles are mid-Carboniferous in age, thus implying that these rock units were remagnetized.
} 
independent of one another and they cannot be combined to yield an overall mean or pole.

Figure 8 is a comparison of Early Carboniferous palaeolatitudes and palaeomagnetic declinations determined from a number of palaeomagnetic studies of the northern Appalachian region. The White Rock and Fisset Brook results in Fig. 8 are documented remagnetizations, whereas the others are derived from strata of Early Carboniferous (Tournaisian through Early Namurian) age. Figure 8 shows that the palaeolatitude and the palaeomagnetic declination determined for the Fisset Brook Formation are similar to those reported for the Early Carboniferous strata in western Newfoundland and central New Brunswick. This implies that the Avalon terrain in northern Cape Breton Island, together with western Newfoundland and the New Brunswick basin (Williams 1978), formed a coherent block at least since Early Carboniferous time. Unfortunately, there are no reliable poles of an equivalent age from interior America with which to compare the data of Fig. 8. We note that the recently published pole for the Mauch Chunk Formation from Pennsylvania (Kent \& Opdyke 1985) is considered Late Namurian in age, and is thus younger than the results from the northern Appalachians shown in Fig. 8. Despite this problem, the lack of evidence for a Carboniferous suture west of central New Brunswick suggests that the Early Carboniferous palaeolatitudes found for this area (Seguin, Singh \& Fyffe 1985) are probably representative of the craton as well. It is likely, therefore, that Avalon probably was already accreted to the craton by the Early Carboniferous.

Figure 9 is a plot of all Carboniferous palaeomagnetic poles determined from Maritime Canada, as well as from the craton (Table 3). The shaded area in the figure is the inferred apparent polar wander (APW) trend for the Carboniferous poles. As seen from the figure, the Early Carboniferous poles group fairly well together, but they are displaced some $10^{\circ}$ from those of Mid-Carboniferous age. The apparent shift in the position of the pole occurred between Early and Late Namurian times, and it implies a change in the palaeolatitude of the northern Appalachian region from approximately $20^{\circ} \mathrm{S}$ to $10^{\circ} \mathrm{S}$. This change is similar in magnitude to the change in the pole position that occurred between Late Namurian time and the end of the Carboniferous (Fig. 9), as previously noted by Roy \& Morris (1983) and Kent \& Opdyke (1985). Also shown in Fig. 9 are Carboniferous palaeopoles derived from the Meguma terrain, which are displaced with respect to the northern Appalachian APW trend. Not all of the Meguma poles from Early Carboniferous rocks are well dated, and some (e.g. W, HG) may be younger remagnetizations of Mid-Carboniferous age. Nevertheless, all of the Meguma poles shown in Fig. 9 are consistent with a counter-clockwise rotation of this terrain with respect to the craton, which others have suggested occurred during its subsequent accretion to $\mathbf{N}$ America in the Late Carboniferous (e.g. Keppie 1982; Spariosu \& Kent 1984; Scotese et al. 1984).

\section{CONCLUSIONS}

As revealed by thermal demagnetization, red siltstones and volcanic flows of the Fisset Brook Formation contain three components of magnetization, which we have called $\mathrm{L}, \mathrm{I}$ and
$H$. The $L$ component is a soft magnetization in the direction of the present-day field, and is inferred to be of recent origin. The intermediate I component, carried by haematite, is of synfolding origin. Directions for I were obtained from linear demagnetization trajectories between $300^{\circ}$ and $550^{\circ}$, and Hoffman-Day intersections, and they yield a mean of $D / I=160^{\circ} /+38^{\circ}\left(k=90.8, \alpha_{95}=5.1^{\circ}\right)$, after 39 per cent of the tilt correction is applied. The $\mathrm{H}$ component has even higher unblocking temperatures, which overlap to a large degree with those of the I component, but analysis of converging great circles appears to indicate a direction for $\mathbf{H}$ which is nearly antipodal to that of the I component. $\mathrm{H}$ is also synfolding, and the best-fit intersection of great circles, after 60 per cent of the tilt correction, yields a mean direction of $D / I=342^{\circ} /-38^{\circ}\left(k=120.9, \alpha_{95}=6.9^{\circ}\right)$.

Both $I$ and $H$ are interpreted as secondary chemical remanent magnetizations (CRMs), acquired some time between the episodes of tilting of the Fisset Brook strata that occurred in Late Tournaisian and Mid-Namurian times, respectively. They are, therefore, late Early Carboniferous in age.

Early Carboniferous palaeolatitudes (and declinations) are in good agreement between Newfoundland, Nova Scotia, New Brunswick and the craton, with the exception of the Meguma terrain, which underwent a counterclockwise rotation with respect to the mainland in the Late Carboniferous. A comparison of all available Carboniferous results from the craton and the northern Appalachians indicates that palaeolatitudes for Nova Scotia changed from about $20^{\circ} \mathrm{S}$ to about $10^{\circ} \mathrm{S}$ in the interval between the Early and Late Namurian and that they changed again from about $10^{\circ} \mathrm{S}$ to $0^{\circ}$ between the Late Namurian and the Stephanian.

\section{ACKNOWLEDGMENTS}

We thank Dr R. A. Jamieson of Dalhousie University for her valuable advice on aspects of the regional geology and sampling. This work was supported by the Division of Earth Sciences, National Science Foundation (grants EAR 81-03130 and EAR 84-07007).

\section{REFERENCES}

Barr, S. M., MacDonald, A. S. \& Blenkinsop, J., 1986. The Cheticamp pluton: a Cambrian granodiorite intrusion in the western Cape Breton Highlands, Nova Scotia, Can. J. Earth Sci., 23, 1686-1699.

Bailey, R. C. \& Halls, H. C., 1984. Estimate of confidence in paleomagnetic directions derived from mixed remagnetizationcircle and direct observational data, J. Geophys., 54, 174-182.

Blanchard, M.-C., Jamieson, R. A. \& More, E. B., 1984. Late Devonian-Early Carboniferous volcanism in western Cape Breton Island, Nova Scotia, Can. J. Earth Sci., 21, 762-764.

Bradley, D. C., 1982. Subsidence in Late Paleozoic basins in the northern Appalachians, Tectonics, 1, 107-123.

Cormier, R. F. \& Kelley, A. M., 1964. Absolute age of the Fisset Brook Formation and the Devonian-Mississippian boundary, Cape Breton Island, Nova Scotia, Can. J. Earth Sci., 1, $159-166$.

Currie, K. L., 1977. A note on post-Mississippian thrust faulting in northwestern Cape Breton Island, Can. J. Earth Sci., 14, 2937-2941.

Dankers, P. H. M., 1981. Magnetic properties of dispersed iron-oxides of known grain size, $P h D$ thesis, University of Utrecht.

Diehl, J. F. \& Shive, P. N., 1981. Paleomagnetic results from the 
Late Carboniferous/Early Permian Casper Formation: implications for northern Appalachian tectonics, Earth planet. Sci. Lett., 54, 281-292.

Fisher, R. A., 1953. Dispersion on a sphere, Proc. R. Soc. A, 217, 295-305.

Halls, H. C., 1976. A least squares method to find a remanence direction from converging remagnetization circles, Geophys. $J$. $R$. astr. Soc., 45, 297-304.

Henry, S. G., 1979. Chemical demagnetization: methods, procedures and applications through vector analysis, Can. J. Earth Sci., 16, 1832-1841.

Hoffman, K. A. \& Day, R., 1978. Separation of multicomponent NRM: a general method, Earth planet. Sci. Lett., 40, 433-438.

Irving, E., \& Strong, D. F., 1984. Paleomagnetism of the Early Carboniferous Deer Lake Group, western Newfoundland: no evidence for mid-Carboniferous displacement of 'Acadia', Earth planet. Sci. Lett., 69, 379-390.

Irving, E. \& Strong D. F., 1985. Paleomagnetism of rocks from the Burin Peninsula, Newfoundland: hypothesis of Late Paleozoic displacement of Acadia criticized, J. geophys. Res., 90, 1949-1962.

Jamieson, R. A. \& Craw, D., 1983. Reconnaissance mapping of the southern Cape Breton Highlands-a preliminary report, in Current Research Part A, pp. 263-268, Pap. geol. Surv. Can. 83-1A.

Johnson, R. \& Van der Voo, R., 1985. Middle Cambrian Paleomagnetism of the Avalon terrane in Cape Breton Island, Nova Scotia, Tectonics, 4, 629-651.

Kelley, D. G., 1967. Baddeck and Whycocomagh map-areas, with emphasis on Mississippian stratigraphy of central Cape Breton Island, Nova Scotia, Mem. geol. Surv. Can., 376.

Kelley, D. G., \& MacKasey, W. O., 1964. Basal Mississippian volcanic rocks in Cape Breton Island, Nova Scotia, Pap. Geol. Surv. Can. 64-34.

Kent, D. V., 1982. Paleomagnetic evidence for post-Devonian displacement of the Avalon platform (Newfoundland), $J$. geophys. Res., 87, 8709-8716.

Kent, D. V. \& Opdyke, N. D., 1979. The early Carboniferous paleomagnetic field of North America and its bearing on tectonics of the northern Appalachians, Earth planet. Sci. Lett., 44, 365-372.

Kent, D. V. \& Opdyke, N. D., 1985. Multicomponent magnetizations from the Mississippian Mauch Chunk Formation of the central Appalachians and their tectonic implications, J. geophys. Res., 90, 5371-5383.

Keppie, J. D., 1979. Geologic Map of the Province of Nova Scotia, Nova Scotia Dept. of Mines and Energy, Halifax, Nova Scotia.

Kirschvink, J. L., 1980. The least squares line and plane and the analysis of paleomagnetic data, Geophys. J. R. astr. Soc., 62, 699-718.

Larson, E. E., Walker, T. R., Patterson, P. E., Hoblitt, P. \& Rosenbaum, J., 1982. Paleomagnetism of the Moenkopi Formation, Colorado Plateau: Basis for long term model of acquisition of CRM, J. geophys. Res., 87, 1081-1106.

McElhinny, M. W., 1973. Paleomagnetism and Plate Tectonics, Cambridge University Press, London.

Miller, J. D. \& Kent, D. V., 1986a. Synfolding and prefolding magnetizations in the Upper Devonian Catskill Formation of Eastern Pennsylvania: implications for the tectonic history of 'Acadia', J. geophys. Res., 91, 12791-12803.

Miller, J. D. \& Kent, D. V., 1986b. Paleomagnetism of the Upper Devonian Catskill Formation from the southern limb of the Pennsylvania salient: possible evidence of oroclinal rotation, Geophys. res. Lett., 13, 1173-1177.

Murthy, G. S., 1985. Paleomagnetism of certain constituents of the Bay St. George sub-basin, western Newfoundland, Phys. Earth planet. Int., 39, 89-107.

Palmer, A. R., 1983. The decade of North American Geology 1983 time scale, Geology, 11, 503-504.

Payne, M. A., Shulik, S. J., Donahue, J., Rollins, H. B. \& Schmidt, V. A., 1981. Paleomagnetic poles for the Carboniferous Brush Creek limestone and Buffalo siltstone from southwestern Pennsylvania, Phys. Earth planet. Int., 25, 113-118.

Perroud, H. \& Van der Voo, R., 1984. Second Magnetizations from the Clinton-type iron ores of the Silurian Red Mountain
Formation, Alabama, Earth planet. Sci. Lett., 67, 391-399.

Poole, W. H., Sanford, B. V., Williams, H. \& Kelley, D. G., 1970. Geology of southeastern Canada, in Geology and Economic minerals of Canada, ed. Douglas, R. S. W., pp. 229-305, Geol. Surv. Can. Econ. Min. Ser.

Pullaiah, G., Irving, E., Buchan, K. L. \& Dunlop, D. J., 1975. Magnetization change caused by burial and uplift, Earth planet. Sci. Lett., 28, 133-143.

Roy, J. L., 1966. Desaimantation thermique et analyse statistique des directions de sediments Carboniferes et Permiens de l'est du Canada, Can. J. Earth Sci., 3, 139-161.

Roy, J. L., 1969. Paleomagnetism of the Cumberland Group and other Paleozoic formations, Can. J. Earth Sci., 6, 663-669.

Roy, J. L., 1977. La position stratigraphique determinee paleomagnetiquement de sediments Carboniferes de Minudie Point, Nouvelle Ecosse: a propos de l'horizon repere magnetique du Carbonifere, Can. J. Earth Sci., 4, 1116-1127.

Roy, J. L. \& Morris, W. A., 1983. Paleomagnetic results from the Carboniferous of North America and the geomagnetic field horizon marker, Earth planet. Sci. Lett., 65, 167-181.

Roy, J. L. \& Park, J. K., 1969. Paleomagnetism of the Hopewell Group, New Brunswick, J. geophys. Res., 74, 594-604.

Roy, J. L. \& Park, J. K., 1974. The magnetization process of certain red beds: vector analysis of chemical and thermal results, Can. J. Earth Sci. 11, 437-471.

Roy, J. L., Robertson, W. A. \& Park, J. K., 1968. The stability of the magnetization of the Hurley Creek Formation, J. geophys. Res., 73, 697-702.

Scotese, C. R., 1985. The assembly of Pangea: Middle and Late Paleozoic paleomagnetic results from North America, PhD thesis, University of Chicago.

Scotese, C. R., Van der Voo, R., Johnson, R. \& Giles, P. S., 1984. Paleomagnetic results from the Carboniferous of Nova Scotia, in Plate Reconstructions from Paleozoic Paleomagnetism, eds Van der Voo, R., Scotese, C. R. \& Bonhommet, N., pp. 63-81, Am. geophys. Un. Geodyn. Ser., 12.

Scott, G. R., 1979. Paleomagnetic studies of the Early Carboniferous St. Joe limestone, Arkansas, J. geophys. Res., 84, 6277-6285

Seguin, M. K., Singh, A. \& Fyffe, L., 1985. New paleomagnetic data from Carboniferous volcanics and redbeds from central New Brunswick, Geophys. Res. Lett., 12, 81-84.

Spariosu, D. J., Kent, D. V. \& Keppie, J. D., 1984. Late Paleozoic motions of the Meguma terrane, Nova Scotia: new paleomagnetic evidence, in Plate Reconstructions from Paleozoic Paleomagnetism, eds Van der Voo, R., Scotese, C. R., \& Bonhommet, N., pp. 82-98, Am. geophys. Un. Geodyn. Ser., N. 12.

Van der Voo, R., 1989. Paleomagnetism of continental North America: the craton, its margins, and the Appalachian belt, in Geophysical Framework of the Continental United States, eds Pakiser, L. C. \& Mooney, W. D., Mem., geol. Soc. Am., in press.

Van der Voo, R. \& Johnson, R., 1985. Paleomagnetism of the Dunn Point Formation (Nova Scotia): high paleolatitudes for the Avalon terrane in the Late Ordovician, Geophys. Res Lett., 12, 337-340.

Walker, T. R., Larson, E. E. \& Holblitt, R. P., 1981. Nature and origin of hematite in the Moenkopi Formation (Triassic), Colorado Plateau: a contribution to the origin of magnetism in red beds, J. geophys. Res., 86, 317-333.

Williams, H., 1978. Tectonic lithofacies map of the Appalachian orogen, Memorial University of Newfoundland, St. John's, Newfoundland.

Williams, H. \& Hatcher, R. D., Jr., 1983. Appalachian suspect terranes, in Contributions to the Tectonics and Geophysics of Mountain Chains, eds. Hatcher, R. D., Jr., Williams, H., \& Zietz, I., pp. 33-54, Mem. geol. Soc. Am. 158.

Wisniowiecki, M. J., Van der Voo, R., McCabe, C. \& Kelly, W. C., 1983. A Pennsylvanian paleomagnetic pole from the mineralized late Cambrian Bonneterre Formation, southeast Missouri, J. geophys. Res., 88, 6540-6548.

Zijderveld, J. D. A., 1967. AC demagnetization of rocks: analysis of results. in Methods in Paleomagnetism, eds Collinson, D. W., Creer, K. M. \& Runcorn, S. K., pp. 254-286, Elsevier, Amsterdam. 